\title{
Bacterial Colonization in Computer Keyboards Posses Health Hazard
}

\author{
S. Sheik Asraf, P. Pavithra, R. Muneeswari, Athira Rajan, S. Ramya, V. Jaya Surya
}

Abstract: Computer keyboards of a teaching laboratory were examined and bacteria were isolated from computer keyboards. The subsequent tests were done for the bacterial isolates: methyl red, vogus proskaur, citrate utilization, urease and TSI. This study paves the way to look at an inanimate object like computer keyboard as potential reservoir of bacteria.

Keywords: Biochemical Analysis, Computer Keyboard, Bacteria

\section{INTRODUCTION}

In a latest study conducted in teaching labs, hospitals and homes, it was found that computer keyboards are potential vector for spread of bacteria such as Staphylococcus Spp., E. coli, Klebsiella, Bacillus Spp. and Pseudomonas Spp. [1]. This lead us to examine the computer keyboards in KARE through microbiology and biochemical tools. We chose the computer keyboards from the computational biology laboratory. Biochemical tests like MR-VP, utilization of citrate, urease and TSI were done for the bacterial isolates. Our research reports the imminent healthiness due to bacteria in computer keyboards to the users.

\section{MATERIALS, METHODS, RESULTS AND DISCUSSION}

\section{A. Isolates of bacteria from the computer} keyboards by swab plate method:

Bacteria were isolated from the computer keyboards by swab culture plate method (Figure 1).

Manuscript received on March 02, 2020.

Revised Manuscript received on November 24, 2021.

Manuscript published on January 30, 2022.

* Correspondence Author

S. Sheik Asraf*, Department of Biotechnology, SBCE, KARE (Deemed to be University), Krishankoil (Tamil Nadu), India. E-mail: s.sheikasraf@klu.ac.in

P. Pavithra, Department of Biotechnology, SBCE, KARE (Deemed to be University), Krishankoil (Tamil Nadu), India. E-mail: pavithra190301@gmail.com

R. Muneeswari, Department of Biotechnology, SBCE, KARE (Deemed to be University), Krishankoil (Tamil Nadu), India. E-mail: muneeswarir2001@gmail.com

Athira Rajan, Department of Biotechnology, SBCE, KARE (Deemed to be University), Krishankoil (Tamil Nadu), India. E-mail: athirarajan099@gmail.com

S. Ramya, Department of Biotechnology, SBCE, KARE (Deemed to be University), Krishankoil (Tamil Nadu), India. E-mail: ramyasolaiyan@gmail.com

V. Jaya Surya, Department of Biotechnology, SBCE, KARE (Deemed to be University), Krishankoil (Tamil Nadu), India. E-mail: vjayasurya2@gmail.com

(C) The Authors. Published by Blue Eyes Intelligence Engineering and Sciences Publication (BEIESP). This is an open access article under the CC BY-NC-ND license (http://creativecommons.org/licenses/by-nc-nd/4.0/)

\section{A. Methyl Red test:}

Methyl Red-Vogus Proskaur broth was kept in the test tubes, proceeded for autoclaving for about 15 minutes at $121^{\circ} \mathrm{C}$ and further introduced with bacteria swabbed from the computer keyboards and later kept for incubation. After incubation, 7-8 drops of MR solution was added [2]. Red color development indicated bacterial isolates were methyl Red positive (Figure 2).

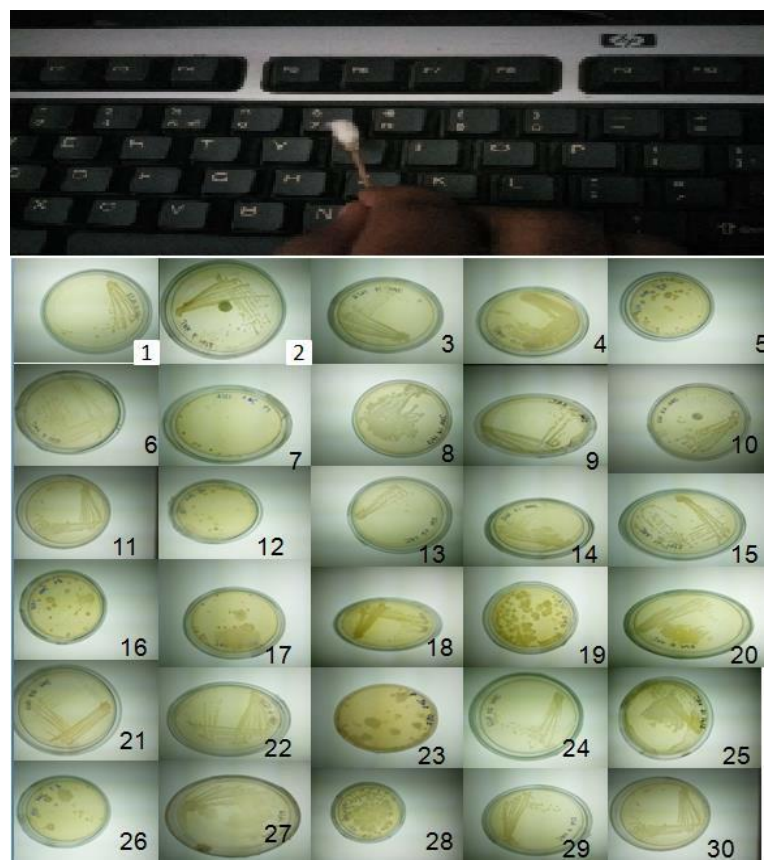

Fig. 1. Swabbing of the bacteria from keyboard's surface. Bacterial isolated from $\mathbf{3 0}$ different keyboards.

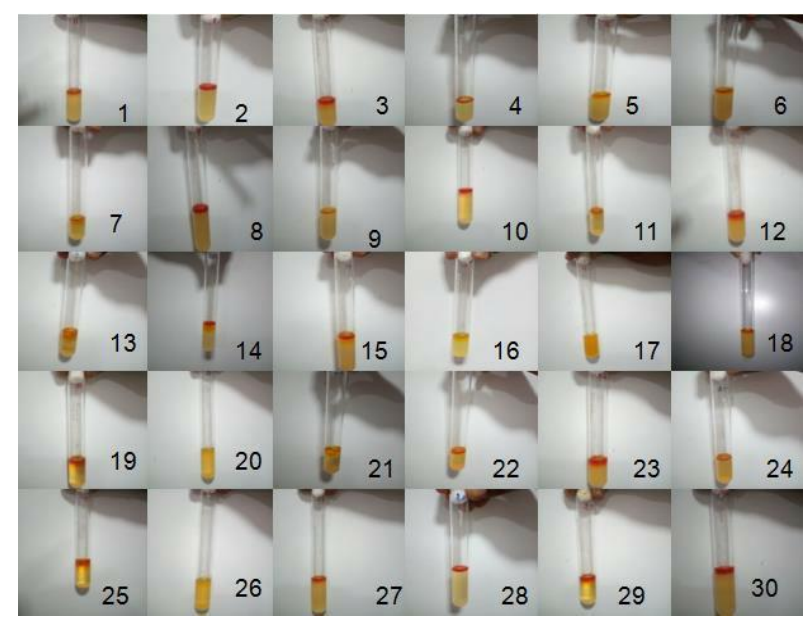

Fig. 2. MR test of the bacteria from 30 different keyboards.

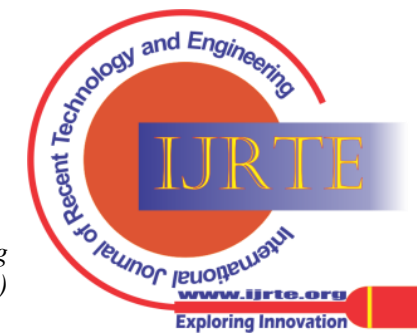




\section{Bacterial Colonization in Computer Keyboards Posses Health Hazard}

\section{B. Vogus Proskaur test:}

Methyl Red-Vogus Proskaur broth was proceeded for autoclaving for about 15 minutes at $121^{\circ} \mathrm{C}$. After autoclaving, the bacteria isolated from the computer keyboard was inoculated into the MR-VP medium and later the test tubes were incubated for a given time period and Barrit's solution was poured and stirred well [3]. The profound rose color pattern indicated that the bacterial isolates were positive for Vogus Proskaur test (Figure 3).

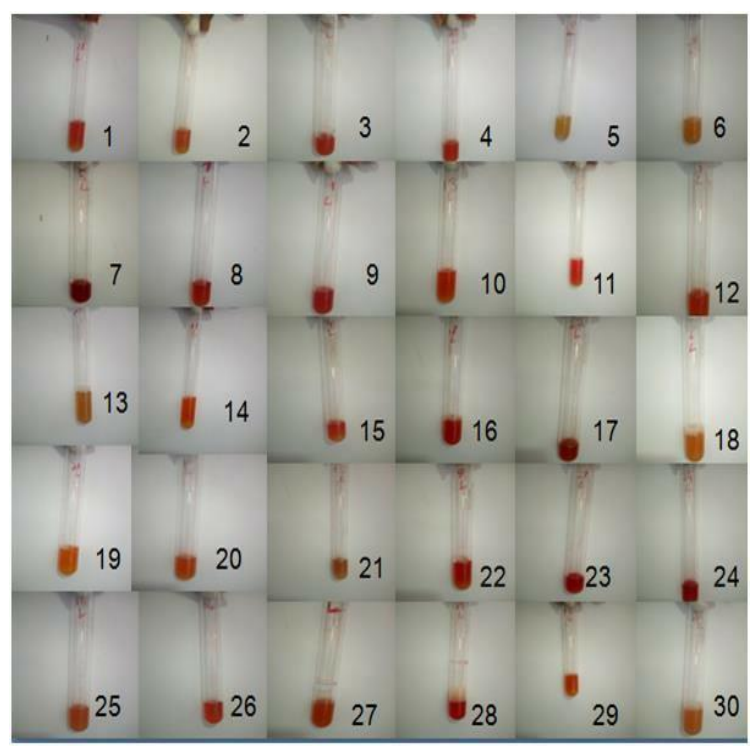

Fig. 3. Vogus Proskaur test for isolated bacteria from 30 different keyboards.

\section{Test for citrate utilization:}

The agar containing simmon's citrate was kept in the test tubes and later proceeded for autoclaving for about 15 minutes at $121^{\circ} \mathrm{C}$ and simmon's citrate slant agar were prepared. The bacteria isolated from computer keyboards were inoculated and kept in incubation [4]. Later, the tubes were examined for hue development. Therefore, the isolates from the keyboards were citrate utilization positive due to the blue color formation (Figure 4).

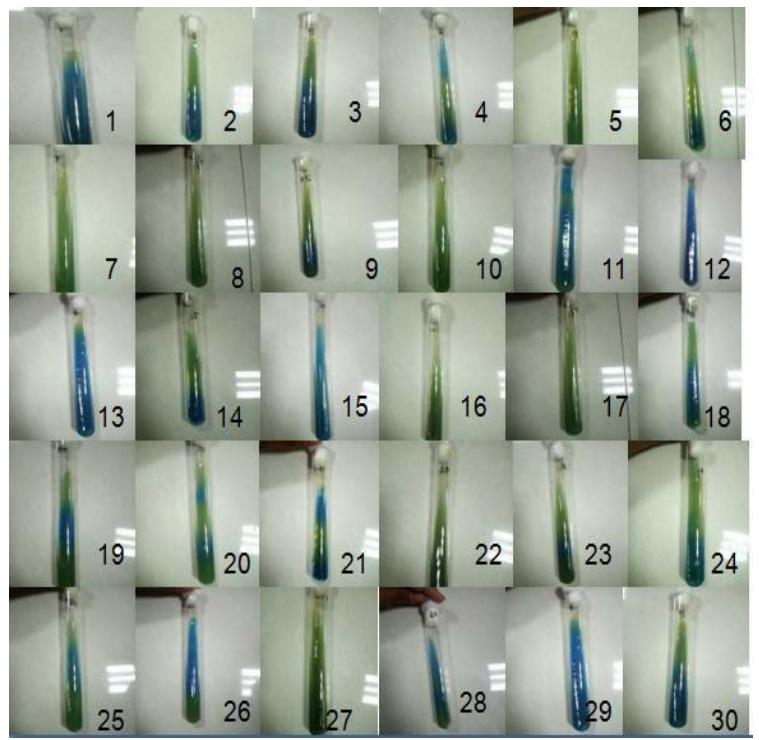

Fig. 4. Citrate utilization test for bacterial isolates from 30 different keyboards.

\section{Urease test:}

Christensen's urea agar was kept in the test tubes, later proceeded for autoclaving for about 15 minutes at $121^{\circ} \mathrm{C}$. The bacteria isolated from computer keyboards were introduced into the agar slants and the test tubes were kept in incubation [5]. Later, Pink color formation was observed and the bacterial isolate from keyboard was Urease positive (Figure 5).

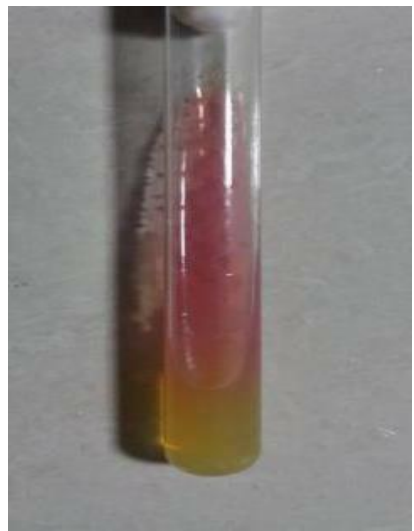

Fig. 5. Test for urease for isolated bacteria from keyboard.

\section{E. TSI test:}

TSI agar was kept in the test tubes and later proceeded for autoclaving for about 15 minutes at $121^{\circ} \mathrm{C}$ and agar slants were prepared and inoculated with bacteria from computer keyboards and kept for incubation [6]. Red colored formation was seen and the bacterial isolate was TSI test positive(Figure 6).

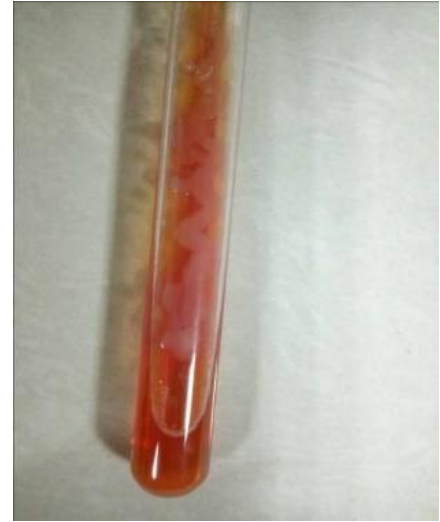

Fig. 6. TSI test for bacterial isolate.

Our study results correlates with the recent findings in a teaching university in Pakistan where it was found that computer keyboards are breeding ground for pathogenic bacteria [7]. More recently, E. coli was found abundant on computer keyboard surfaces [8]. Similarly, in 2015, Pseudomonas species, S. aureus, S. epidermis, E. coli, Klebsiella species and $S$. haemolytics were found to present in computer keyboards [9]. In a study carried out in 2012, it was found that pathogenic bacteria like Staphylococcus sp. Clostridium sp. Enterococcus sp., Bacillus sp. had infested the computer keyboards of hospital and library [10]. 


\section{CONCLUSION}

Thus, computer keyboards are breeding grounds of bacteria and it is necessary to follow the basic practices like wiping the computer keyboards with disinfectants to eliminate the spread of pathogenic bacteria from one person to another.

\section{ACKNOWLEDGEMENT}

The management authorities of KARE are thanked for providing the research laboratory facilities.

\section{REFERENCES}

1. F.R. Saleh. "The Role of Computer Keyboards in spreading pathogenic Bacteria in Hospitals, teaching labs and Homes; And the Effect of Using Alcohol Wipes to Eliminate Contamination." Microbioz Journals, Journal of Microbiology and Biomedical Research. vol. 1 (5), 2015, pp. 1-5.

2. A.L. Barry, K. L. Bernsohn, A. P. Adams, L. D. Thrupp. "Improved 18-hour methyl red test." Appl. Environ. Microbiol. vol. 20(6), 1970, pp.866-870.

3. C.H. Werkman. "An improved technic for the Voges-Proskauer test." Journal of bacteriology vol. 20(2), 1930, pp.121.

4. T.N.S Raghavachari. "The Applicability of Koser's Citrate Utilization Test to Sanitary Water Analysis in India." Indian Journal of Medical Research. vol. 14, 1926, pp. 47-51.

5. W.B. Christensen. "Urea decomposition as a means of differentiating Proteus and paracolon cultures from each other and from Salmonella and Shigella types." Journal of Bacteriology. vol. 52(4), 1946, pp. 461.

6. J.K. Skillern, T.L. Overma, "Oxidase testing from Kligler's iron agar and triple sugar iron agar slants." Current Microbiology. vol. 8(5), 1983, pp. 269- 271.

7. K. Malik, N. Naeem "Study of bacteria on computer's mice and keyboards.” Int J Curr Microbiol App Sci, 3(4), 2014, pp. 813-23.

8. T.R.K Reddy, H.J. Kim. "Facile synthesis of silver nanoparticles and its antibacterial activity against Escherichia coli and unknown bacteria on mobile phone touch surfaces/computer keyboards". Applied Physics A, 122(7), 2016, pp.652.

9. S.S.E. Mohammed. "Detection of Multi-drugs Resistance among Bacteria Isolated from Computers' Keyboards” Doctoral dissertation, Sudan University of Science \& Technology. 2015.

10. Y.C. Manni. "Pathogenic bacteria harbored by computer keyboards in hospital versus libraries" Doctoral dissertation, Quinnipiac University. 2012.

\section{AUTHORS PROFILE}

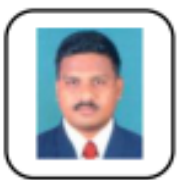

S. Sheik Asraf is an assistant professor working in Kalasalingam Academy of Research and Education. He had completed his Ph.D. thesis entitled "Computational and functional genomic analysis of beta-lacatamases, beta-galactosidase and cellulose synthase operon in Zymomonas mobilis" in Madurai Kamaraj University, Madurai in 2013. He has research experience in the broad areas of bioinformatics, genomics and microbiology. He is a recipient of Junior Research Fellowship from Department of Science and Technology, Government of India. He has received travel grants from the following agencies and institutes for participation in events held in India: UNESCO, IUBMB, RCBTE, ICGEB, National Science Foundation, IndoUS Science and Technology Forum and Department of Biotechnology. He has published 15 Journal publications, 3 Book chapters, 33 conference abstracts. His current research focus is metagenomics and culture dependent study of inanimate objects.

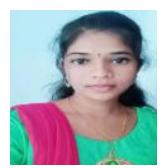

P. Pavithra is in the final year of B. Tech. Biotechnology from Kalasalingam Academy of Research and Education. Her B. Tech. Project is entitled "in silico and functional analysis of putative beta-galactosidases of Cellulomonas gilvus ATCC 13127”.

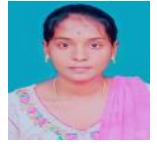

R. Muneeswari is in the final year of $B$. Tech Biotechnology from Kalasalingam Academy of Research and Education. Her B. Tech. Project is entitled "in silico and functional analysis of putative beta-galactosidases of Cellulomonas gilvus ATCC 13127”.

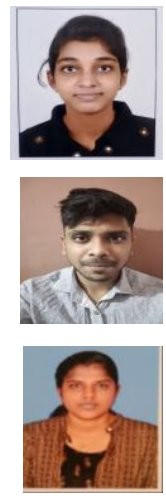

Athira Rajan is in the final year of B. Tech Biotechnology from Kalasalingam Academy of Research and Education. Her B. Tech. Project is entitled "in silico and functional analysis of putative beta-galactosidases of Cellulomonas gilvus ATCC 13127”.

Jaya Surya $\mathbf{V}$ is in the final year of $B$. Tech Biotechnology from Kalasalingam Academy of Research and Education.

Ramya S, is in the final year of B. Tech. Biotechnology from Kalasalingam Academy of Research and Education.
Published By:

Blue Eyes Intelligence Engineering and Sciences Publication (BEIESP)

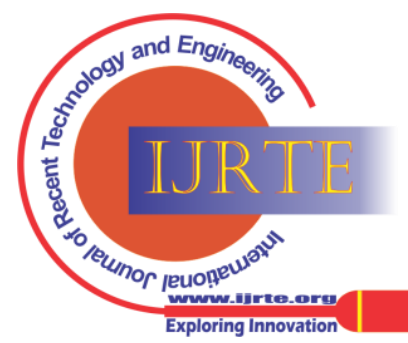

